\title{
Eco-Friendly Control Strategies of Green Stink Bug, Nezara viridula L. (Hemiptera: Pentatomidae): Repellency and Toxicity Effects of Callistemon citrinus, Bottle Brush Essential Oil \\ Rehab M. El-Gendy and Samah N. El-Shafiey \\ Plant Protection Research Institute, Agriculture Research Center, Dokki, Giza \\ Rehabgendy4@gmail.com
}

\section{ABSTRACT}

The bioactivity of Callistemon citrinus leaves essential oil against green stink bug, Nezara viridula was evaluated as alternative eco-friendly pesticide. The tested essential oil have high insecticidal activity to $N$. viridula adult where, the lethal concentrations of $\mathrm{LC}_{10}$, $\mathrm{LC}_{25}$ and $\mathrm{LC}_{50}$ were recorded $(105.22,536.80$ and $3274.72 \mathrm{ppm})$, respectively. The repellent effects on $N$. viridula adult of the three tested concentrations were $48.01,56.35$ and $81.33 \%$ after one hour of exposure time, respectively. The chemical composition analysis of bottle brush essential oil by GC/MS revealed 24 compounds represented $99.47 \%$ of the whole amount oil. The major constituent 1,8 cineole represented $(73.81 \%)$ followed by $\alpha$ pinene $(13.13 \%)$, D-limonene (5.50\%), $\beta$-pinene $(2.49 \%)$ and $\alpha$-Terpineol $(1.10 \%)$ assumed $96.03 \%$ of the total oil composition, while the minor components were $3.97 \%$. Treatment with all concentrations of $C$. citrinus essential oil exhibited some physiological defects that cleared in the reduction in total soluble protein levels and elevation in carbohydrate hydrolyzing enzymes, nonspecific estrases and acid \& alkaline phosphatases activities. Moreover, the $\mathrm{LC}_{50}$ inhibited acetyl cholinesterase activity in treated adults. Therefore the oil proved high potency in controlling the $N$. viridula.

Keywords: Callistemon citrinus, Nezara viridula, repellent effect, essential oil, enzymes activities

\section{INTRODUCTION}

There are many species of stink bugs, characterized by shield-shaped bodies and producing a strong disagreeable odor when handled. Stink bugs are consider an economic pest of most crops as cotton, soybean, tomato therefore, the control of this pest is more difficult. Their damage varies depending on the crop phenology when attacked, species of plant and the stage of development (Gore et al., 2006 and Mollah et al., 2017). Adults and nymphs have piercing sucking mouthparts, which they use to pierce the peel or hull of fruiting structures and feed on the inner contents as in butter beans, green beans and soybean during pod formation which induce deformed seeds and reduce oil yield (Panizzi, 1997). Seed that are damaged when small usually fail to develop while larger seed will have sunken white or discolored areas where the stink bugs fed Willrich et al. (2004).

The C. citrinus, red bottle brush plant, family Myrtaceae is native from Australia now is widespread in many countries due to its very attractive appearance especially in mild climates countries Cornes (2006). The use of natural pesticides to protect crops because of their low toxicity to human beings and minimal environmental impact in comparable of most synthetic pesticides Isman (2000) and overcome the problem of development of resistance in insects Viswan et al. (2014). Recently many plants subjected to further investigation and their secondary metabolites have been formulated as botanical pesticides in plant protection and biological control. Essential oils, which are secondary metabolites used for defense against herbivorous, have been extracted and utilized as natural pesticides, antifeeding, growth regulators inhibitors and repellents, Suthisut et al.(2011). Previous studies have reported antifungal Nguefack et al. (2007), antibacterial Seyydnejad et al. (2010) and insecticidal activity (Ndomo et al. 2010) of volatile compounds from Callistemon species. Therefore, the current study made an attempt to determine the chemical composition and insecticidal activity of $C$. citrinus essential oils from leaves on the sting bug, $N$. viridula and establishing eco-friendly control strategy.

Nowadays natural pesticides based on plant extracts and essential oils represent alternative crop protectants and used in the control of several pests. The aim of this study is throw light on the deficiency in information on the effectiveness of repellents against $N$. viridula and other phytophagous hemipterans.

\section{MATERIALS AND METHODS}

Tested insect:

The sting bug, $N$. viridula subjected to bioassay studies were obtained from Sharkia province fields and reared on Okra leaves, Abelmoschus esculentus under constant conditions $25 \pm 5{ }^{\circ} \mathrm{C}$ and $65 \pm 5 \% \mathrm{RH}$ and $12: 12 \mathrm{~h}$ photo phase in physiology department, Branch of Plant Protection Research Institute at Zagazig, Sharkia.

Essential oil Extraction.

The plant under investigations was collected from various localities in Sharkia province. The $C$. citrinus fresh leaves of (500 gm.) were subjected to hydro distillation in two liters of distilled water until all essential oil was extracted afterword dried over anhydrous sodium sulfate and stored at $4^{\circ} \mathrm{C}$ until use.

\section{Identification of oil components}

The identification of oil components analysis was carried out in National research Center, Cairo, Egypt according to the method of Likenes and Nickerson (1966).

The bottle brush essential oil were analyzed on Gas chromatography Mass Spectrometry HP 6890 Series A (Agilent) equipped with column (Thermo Scientific (TR5MS), 5\% Phenyl Polysil Phenylene Siloxane; $30 \mathrm{~m}$ x 0.25 $\mathrm{mm}$ i.d.; $0.25 \mu \mathrm{m}$ film thickness). The column flow rate was $1.00 \mathrm{ml} \mathrm{He} / \mathrm{min}$. Temperature program: initial temperature $50^{\circ} \mathrm{C}$ for 5 minutes, temperature rate 4 ${ }^{\circ} \mathrm{C} / \mathrm{min}$, final temperature $250{ }^{\circ} \mathrm{C}$. The injector temperature was $250^{\circ} \mathrm{C}$; injection volume $1 \mu \mathrm{L}$. Empirical identification of the essential oil components were conducted by comparison of their relative retention times (RT) and their relative retention index (RRI) to a series of n-alkanes. Mass spectrum matching was aided by commercial libraries; NIST, Replib, wiley9, and mainlib.

Bioassay

Toxicity evaluation:

Serial concentrations of aqueous solutions of the tested essential oil were prepared. Okra leaves were dipped 
in each mentioned concentration for 10 seconds then left to dry at room temperature, treated leaves were put separately in glassy jars covered with muslin. Three replicates of each concentration were prepared used 20 adult of $N$. viridula were transferred to each one. The mortality percentages were recorded after $24 \mathrm{~h}$. Mortality data were corrected according to Abbott's formula (1925). The $\mathrm{LC}_{10}, \mathrm{LC}_{25}$ and $\mathrm{LC}_{50}$ values were determined by using Probit-analysis of Biostat version 5 Analystsoft program.

\section{Repellency assay}

The repellent activity of $C$. citrinus oil was performed in multichannel olfactometer, which consisted of a circular central arena with five protruding tubes on the sides orthogonal to each other. These tubes connected to the five odor-chambers. The okra leaves treated with 105.22, 536.80 and $3274.72 \mathrm{ppm}$ of bottle brush essential oil putted in 3arms, respectively and the untreated one putted in other arm, the rest 1 arm closed with cotton. 20 individual of adult sting bugs released in the central arena under lab conditions $25 \pm 5^{\circ} \mathrm{C}$ and $65 \pm 5 \% \mathrm{RH}$ and $12: 12 \mathrm{~h}$ photo phase three replicates were occurred. After $1,12 \mathrm{~h}$. the number of insects in each arm, and the number that remained in the central arena, were counted. Percentage of repellency $(\mathrm{PR})$ was calculated according to the following equation: $\mathrm{PR}=[(\mathrm{NC}-\mathrm{NT}) /(\mathrm{NC}+\mathrm{NT})] \times 100$, where $\mathrm{NC}$ was the number of $N$. viridula adult on the untreated tube and NT was the number of insects on the treated tubes after the exposure intervals Akhtar et al., (2012).

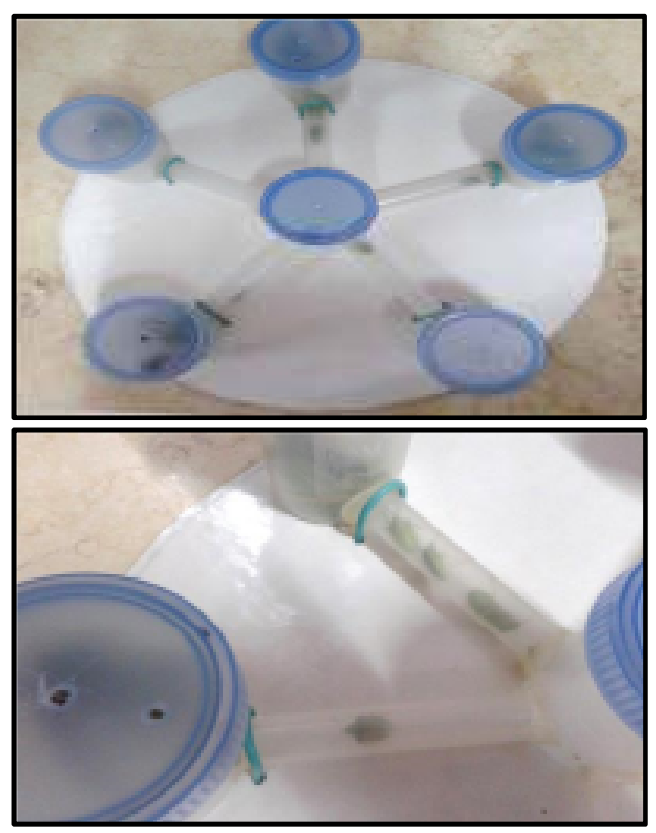

Biochemical studies:

Samples of 3 replicates of $N$. viridula adult were collected after $24 \mathrm{~h}$. of treatments with $\mathrm{LC}_{10}, \mathrm{LC}_{25}$ and $\mathrm{LC}_{50}$. The untreated one was used as control. Samples were homogenized in distilled water using a Teflon homogenizer surrounded with a jacket of crushed ice. The homogenates were centrifuged at 6000 r.p.m. for 10 minutes at $5^{\circ} \mathrm{C}$. The supernatant were stored at $-20^{\circ} \mathrm{C}$ until analysis.

\section{Total soluble protein}

Colorimetric determination of total soluble protein was carried out as described by Gornall et al. (1949).

\section{Carbohydrases enzymes activity:}

The carbohydrases enzymes; invertase, amylase and trehalase activities were determined based on the digestion of sucrose, starch and trehalose, respectively, according to (Ishaaya and Swirski, 1976).

\section{$\alpha$ and $\beta$ estrases}

the activeties of $\alpha$ estrases and $\beta$ estrases, as nonspecific estrases, were colorimetrically measured by Van Asperen (1962) method by using substrate $\alpha$-naphthyl acetate and $\beta$-naphthyl acetate, respectively.

\section{Acid and alkaline phosphatases}

The acid and alkaline phosphatase activities were estimated by using Powell and Smith (1954) method as the amount of phenol that released by enzymatic hydrolysis from disodium phenyl phosphate (substrate).

\section{Acetyl cholinesterase determination}

The activity AchE (Acetyl cholinesterase) was determined by the Simpson et al. (1964) method using acetyl choline bromide (AchBr) as substrate.

\section{Statistical analysis}

The repellency test results were subjected to (ANOVA) variance analysis in addition to the Tukey's least significant difference to estimate significance differences between samples by Costat (2005) version 6.311 .

\section{RESULTS}

\section{Susceptibilty of N. viridula to Callistemon citrinus, essential oil.}

Regarding Figure (1) the insecticidal action of four serial concentrations of $C$. citrinus essential oil on adult $N$. viridula after $24 \mathrm{hr}$ of treatment were evaluated. The high toxic effect $(70 \%)$ mortality recorded at $10000 \mathrm{ppm}$ while the lowest concentration $(625 \mathrm{ppm})$ caused $30 \%$ mortality. The observed data indicate that the volatile oil of $C$. citrinus have toxic effect on $N$. viridula adult.

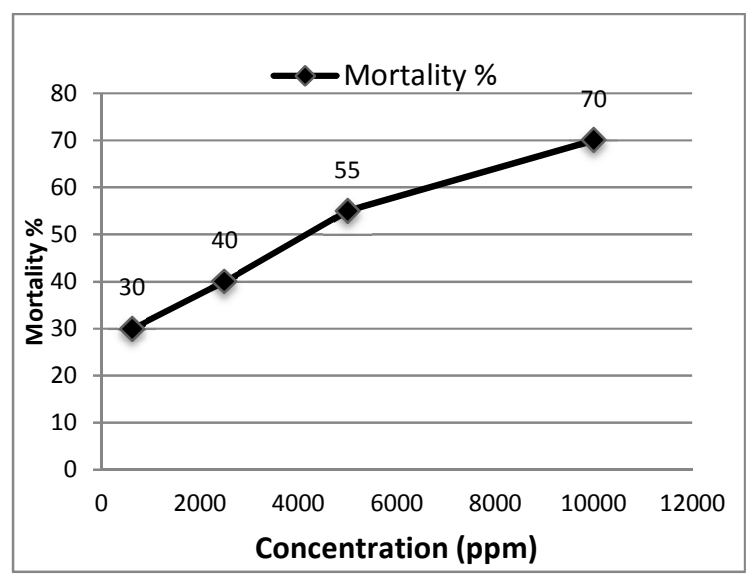

Fig. 1. Effect of Callistemon citrinus essential oil on adult mortality of Nezara viridula.

Toxicity bioassay:

The toxic effect of $C$. citrinus were listed in table (1) the $\mathrm{LC}_{10}, \mathrm{LC}_{25}$ and $\mathrm{LC}_{50}$ were $(105.22,536.80$ and $3274.72 \mathrm{ppm})$, respectively with slope 0.8585 and Chi-square 0.2811 for $N$. viridula adult after $24 \mathrm{~h}$ of treatment. 
Table 1. Toxic effect of different concentration of Callistemon citrinus essential oil.

\begin{tabular}{|c|c|c|c|c|c|}
\hline & \multirow{2}{*}{$\begin{array}{c}\text { Concentration } \\
\text { ppm }\end{array}$} & \multicolumn{2}{|c|}{ Confidence limits } & \multirow{2}{*}{ slope } & \multirow{2}{*}{$\begin{array}{c}\text { Chi-square } \\
\left(\chi^{2}\right) \\
\end{array}$} \\
\hline & & Lower & upper & & \\
\hline $\mathrm{LC}_{10}$ & 105.22 & 0.0 & & & \\
\hline $\mathrm{LC}_{25}$ & 53 & 1.906 & 1403.49 & 0 & 0.2811 \\
\hline $\mathrm{LC}_{50}$ & 3274.72 & 1115.16 & 11406.19 & & \\
\hline
\end{tabular}

\section{Repellency assay}

The $C$. citrinus essential oil exhibited repellant effect against adults of $N$. viridula, dependent on the dose $(\mathrm{P}<0.05)$. Furthermore, the repellent action increased slightly when the insects were exposed for more time (Table 2$)$ at $3274.72 \mathrm{ppm}\left(\mathrm{LC}_{50}\right)$ from $81.33 \%$ after $1 \mathrm{~h}$. to $82.66 \%$ after $12 \mathrm{~h}$. While, at concentrations of $\mathrm{LC}_{25}$ (536.80) and $\mathrm{LC}_{10}$ (105.22), the repellency changed from $56.35 \%$ to $49.16 \%$ and from $48.01 \%$ to $42.66 \%$ after 1 and $12 \mathrm{~h}$ exposure times, respectively.

Table 2. Repellency effect of Callistemon citrinus, essential oil on $N$. viridula

\begin{tabular}{lcc}
\hline $\begin{array}{l}\text { Concenterations of } \\
\text { Callistemon citrinus }\end{array}$ & $\mathbf{1 h .}$ & $\mathbf{1 2 h}$. \\
\hline $\mathrm{LC}_{10}$ & $48.01^{\mathrm{b}} \pm 1.01$ & $42.66^{\mathrm{b}} \pm 1.76$ \\
$\mathrm{LC}_{25}$ & $56.35^{\mathrm{b}} \pm 0.45$ & $49.16^{\mathrm{b}} \pm 3.87$ \\
$\mathrm{LC}_{50}$ & $81.33^{\mathrm{a}} \pm 9.49$ & $82.66^{\mathrm{a}} \pm 10.10$ \\
L.S.D. & 19.09 & 21.90 \\
$\mathrm{P}$ & $0.0127 *$ & $0.0089 * *$ \\
\hline L.S.D. means low significance differences at $\mathbf{P}<\mathbf{0 . 0 5}$
\end{tabular}

Chemical compounds of $\boldsymbol{C}$. citrinus essential oil

The obtained analysis results of GC-MS showed that the essential oil of C. citrinus contains 24 constituents represented by $99.47 \%$ of the whole amount oil (Table 3). 1,8- cineole (73.81) and $\alpha$ pinene (13.13) are the major components followed by Dlimonene (5.50), $\beta$-pinene (2.49) and $\alpha$-Terpineol (1.10) percentages with $96.03 \%$ of the total oil composition. The other components are traces compound (3.97\%). The main component of the tested oil is 1,8 - cineole.

\section{Biochemical assay}

The biochemical responses of supernatant obtained from adult $N$. viridula homogenates were assessed after $24 \mathrm{~h}$. of treatments with the $\mathrm{LC}_{10}, \mathrm{LC}_{25}$ and $\mathrm{LC}_{50}$ of $C$. citrinus essential oil. The changes in the amount of total soluble protein and the carbohydrate hydrolyzing enzymes activities; (trehalase, invertase, amylase), acid \& alkaline phosphatases, $\alpha \& \beta$ esterase and acetylcholinesterase enzymes were observed.

The total soluble protein:

Data in Fig (2a) cleared that the three concentrations of $C$. citrinus essential oil caused reduction in the amount of total soluble protein, in general. The highest reduction (5.35) observed at $\mathrm{LC}_{50}$ followed by $\mathrm{LC}_{25}$ (8.43) while $\mathrm{LC}_{10}$ caused slightly decrease (13.96) as compared to control (14.54 mg/gm. b. wt.).

Carbohydrate hydrolyzing enzymes:

Data presented in Fig (2b) show the effect of the tested oil at different concentrations on carbohydrate hydrolyzing enzymes in the homogenate adult of $N$. viridulla. It is explained that all concentration induced significant elevation in the activity of amylase, invertase and trehalase. The maximum elevation of invertase

(28.17) and trehalase (15.70) exhibited at $536.80 \mathrm{ppm}$ $\left(\mathrm{LC}_{25}\right)$, while the maximum activity of amylase (6.56) detected at $105.22 \mathrm{ppm}\left(\mathrm{LC}_{10}\right)$ as compared to the control activity of amylase, invertase and trehalase (2.07, 0.82 and $3.15 \mathrm{mg}$ glucose $/ \mathrm{g}$. b. wt./min), respectively.

Table 3. The main compounds of the Callistemon citrinus essential oil from leaves.

\begin{tabular}{|c|c|c|c|}
\hline $\mathbf{R t}$ & Compound & Area\% & CAS number \\
\hline 3.87 & $\begin{array}{l}\text { 3-Pentanone, 2,4- } \\
\text { dimethyl- }\end{array}$ & 0,05 & $\begin{array}{c}\text { 565-80-0 } \\
\text { Wiley9 }\end{array}$ \\
\hline 5.50 & Isopentyl acetate & 0.07 & $\begin{array}{c}\text { 123-92-2 } \\
\text { Wiley9 }\end{array}$ \\
\hline 6.77 & $\alpha$-Thujene & 0.12 & $\begin{array}{c}2867-05-2 \\
\text { Wiley9 }\end{array}$ \\
\hline 7.04 & $\alpha$-Pinene & 13.13 & $\begin{array}{l}80-56-8 \\
\text { Wiley9 }\end{array}$ \\
\hline 8.56 & $\beta$-Pinene & 2.49 & $\begin{array}{c}127-91-3 \\
\text { Wiley9 }\end{array}$ \\
\hline 9.48 & Pseudolimonene & 0.08 & $\begin{array}{c}499-97-8 \\
\text { Wiley9 }\end{array}$ \\
\hline 9.58 & $\alpha$-Phellandrene & 0.33 & $\begin{array}{l}\text { 99-83-2 } \\
\text { Wiley9 }\end{array}$ \\
\hline 9.96 & $\alpha$-Terpinene & 0.16 & $\begin{array}{l}99-86-5 \\
\text { Wiley9 }\end{array}$ \\
\hline 10.33 & p-Cymene & 0.04 & $\begin{array}{l}99-87-6 \\
\text { Wiley9 }\end{array}$ \\
\hline 10.45 & D-Limonene & 5.50 & $\begin{array}{l}\text { 5989-27-5 } \\
\text { Replib }\end{array}$ \\
\hline 10.64 & 1,8-Cineole & 73.81 & $\begin{array}{l}\text { 470-82-6 } \\
\text { Mainlib }\end{array}$ \\
\hline 11.62 & $\gamma$-Terpinene & 0.62 & $\begin{array}{l}99-85-4 \\
\text { Wiley9 }\end{array}$ \\
\hline 12.74 & $\alpha$-Terpinolene & 0.09 & $\begin{array}{c}586-62-9 \\
\text { Wiley9 }\end{array}$ \\
\hline 13.44 & Linalool & 0.22 & $\begin{array}{l}\text { 78-70-6 } \\
\text { Wiley9 }\end{array}$ \\
\hline 14.44 & Fenchol & 0.04 & $\begin{array}{c}\text { 1632-73-1 } \\
\text { Wiley9 }\end{array}$ \\
\hline 15.42 & trans-Pinocarveol & 0.04 & $\begin{array}{c}547-61-5 \\
\text { Wiley9 }\end{array}$ \\
\hline 16.86 & Borneol & 0.06 & $\begin{array}{l}\text { 507-70-0 } \\
\text { Replip }\end{array}$ \\
\hline 17.17 & Terpinen-4-ol & 0.74 & $\begin{array}{c}562-74-3 \\
\text { Wiley9 }\end{array}$ \\
\hline 17.91 & $\alpha$-Terpineol & 1.10 & $\begin{array}{l}98-55-5 \\
\text { Wiley9 }\end{array}$ \\
\hline 27.46 & $\begin{array}{l}\text { trans- } \\
\text { Caryophyllene }\end{array}$ & 0.37 & $\begin{array}{l}87-44-5 \\
\text { Wiley9 }\end{array}$ \\
\hline 29.04 & Humulene & 0.05 & $\begin{array}{c}\text { 6753-98-6 } \\
\text { Wiley9 }\end{array}$ \\
\hline 30.47 & Virdiflorene & 0.04 & $\begin{array}{c}21747-46-6 \\
\text { Wiley9 }\end{array}$ \\
\hline 34.40 & $\begin{array}{l}\text { Caryophyllene } \\
\text { oxide }\end{array}$ & 0.18 & $\begin{array}{l}\text { 1139-30-6 } \\
\text { Replib }\end{array}$ \\
\hline 34.56 & (-)-Globulol & 0.14 & $\begin{array}{c}\text { 489-41-8 } \\
\text { Wiley9 }\end{array}$ \\
\hline \multicolumn{2}{|c|}{ Total identified } & & $\begin{array}{c}99.47 \\
0.53\end{array}$ \\
\hline
\end{tabular}




\section{Nonspecific estrases $(\alpha$ and $\beta)$ :}

It is worthy to mention that the activity of $\alpha$ and $\beta$ estrases Fig (2c) increased at all tested concentrations of $C$. citrinus essential oil. The highest increase recorded at $\mathrm{LC}_{50}, 0.37$ and 14.58 followed by 0.14 and 9.66 at $\mathrm{LC}_{25}$ than control 0.05 and $0.16 \mu \mathrm{g} \alpha-\beta$ naphthol $/ \mathrm{min} / \mathrm{g}$.b.wt for $\alpha$ and $\beta$ estrases, respectively.

Acid and Alkaline phosphatases (ACP, ALP):

The obtained results in Fig (2d) illustrated that all concentrations of tested oil recorded an elevation in ACP activity in the supernatant of the treated homogenate of adult $N$. viridulla. The abnormal activation (134.44) caused

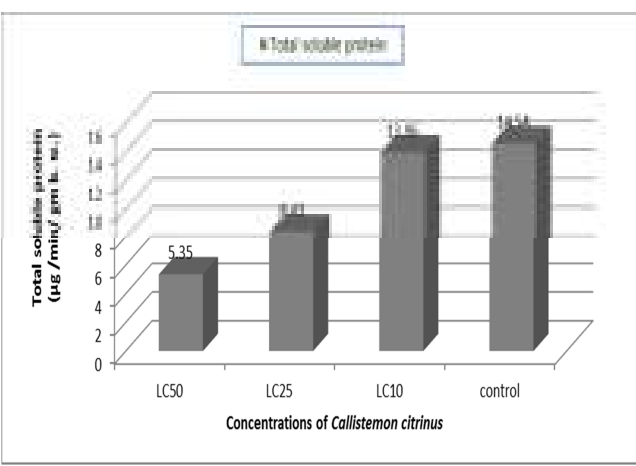

(a)

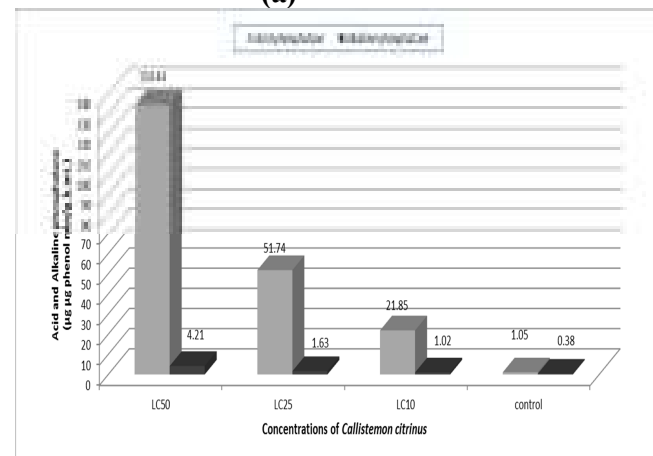

(c) at $\operatorname{LC}_{50}(3274.72 \mathrm{ppm})$ while the ACP activity of control (1.05 $\mu \mathrm{g}$ phenol $/ \mathrm{min} / \mathrm{g}$. b.wt.). All the treatments caused slightly elevation of ALP activity in homogenate $N$. viridula adult.

\section{Acetylcholinesterase activity:}

It is obvious from Fig. (2e) that the level of cholinesterase activity in the treated adult of $N$. viridula increased as compared with the level of untreated one in exception with $\mathrm{LC}_{50}$ which caused inhibition of this enzyme. The cholinesterase activities in treated adult were 1.73, 1.29 and $0.15 \mu \mathrm{g} \mathrm{AChBr} / \mathrm{min} / \mathrm{gm} \mathrm{b}$. w. at $\mathrm{LC}_{10}, \mathrm{LC}_{25}$ and $\mathrm{LC}_{50}$, respectively, while it was 0.53 in control adult.

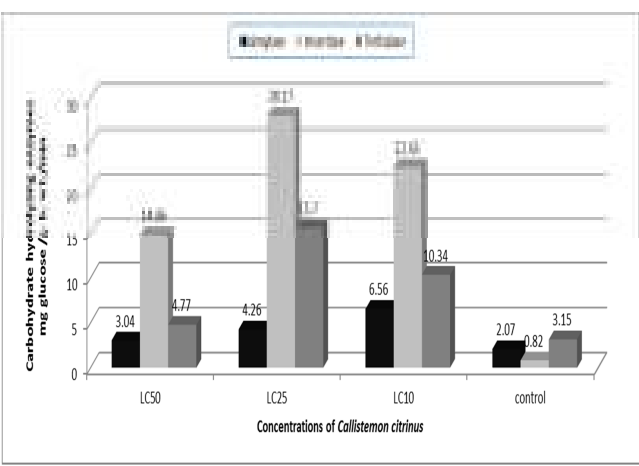

(b)

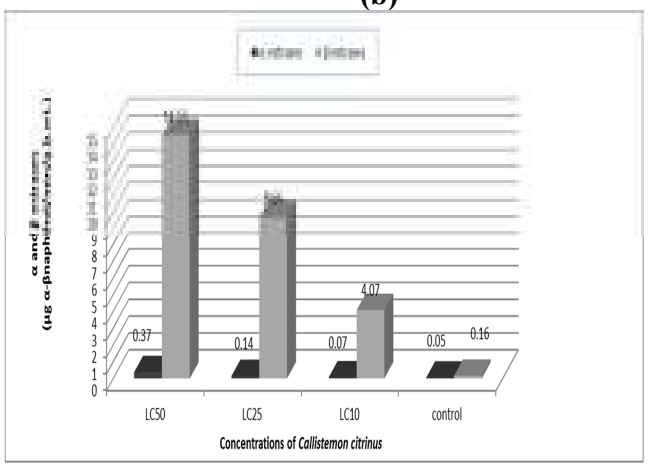

(d)

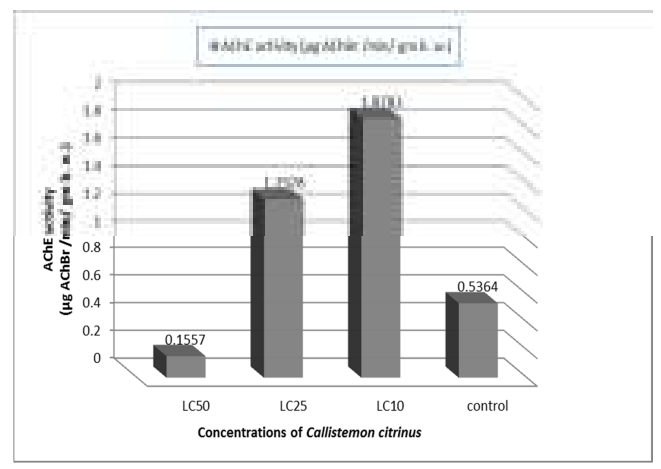

(e)

Fig. 2. Biochemical parameters in homogenate $N$. viridula adult treated with $C$. citrinus leaves essential oil.

\section{DISCUSSION}

The obtained results from GC-MS analysis demonstrated that the essential oil of $C$. citrinus leaves contains 1,8- cineole (73.81) and $\alpha$ pinene (13.13) are the major components followed by D-limonene (5.50), $\beta$ pinene (2.49) and $\alpha$-Terpineol (1.10) percentages with $96.03 \%$ of the total oil composition. The high repellent activity may regarded to the presence of 1,8 -cineole.
The composition of the essential oils from these studies compared with previous one emphasized that the major components of the $C$. citrinus essential oil were similar with different percentages. These results are in harmony with those studies by (Oyedeji et al. 2009 and Fall et al. 2017) indicated that the major compounds of $C$. viminalis oil were 1.8 -cineole $(58.12 \%)$, limonene (9.72\%), $\alpha$-terpineol (9.56\%) and $\alpha$-pinene (2.49\%). Salem 
et al. (2013) stated that the essential oil of $C$. viminalis leaves contain 14 identified constituents. The major component were 1,8 - cineole and $\alpha$ pinene $(64.53 \& 9.69$ \%). Moreover, Jazet et al. (2009) reported the identified component of $C$. citrinus essential oil from Cameroon were 1,8-cineole (73.8\%), $\alpha$-pinene (16.3\%) and $\alpha$-terpineol (4.8\%). Many studies elucidated that 1,8 - cineole is the major compound in C. citrinus essential oil (Shrestha et al., 2015; Aweke and Yeshanew; 2016 and Andola et al., 2017).

The family myrtaceae has major compounds characterized by insecticidal properties, such as 1.8cineole, limonene, $\alpha$-terpineol and $\alpha$-pinene. The insecticidal action of 1.8-cineole has been evaluated against several insects. The repellent effect of this compound against Sitophilus granarius and Sitophilus zeamais were detected (Liska et al, 2010). In addition, $\alpha$ pinene showed insecticidal activity against Tribolium confusum (Chaubey, 2012). Moreover Zandi-Sohani et al. (2013) revealed that the $C$. citrinus essential oil has the repellent and insecticidal activity against the adult males of Callosobruchus maculatus (F.) and the essential oil exhibited that the oil was toxic in the fumigation test at LD50 values 12.88 and $84.4 \mu \mathrm{L} \cdot \mathrm{L}-1$ to males and females, respectively. Both the essential oils from leaves and flowers of $C$. viminalis exhibited a repellent activity against the Maize persicae. It can be inferred that the principle compounds (1.8-cineol and $\alpha$-pinene) in the essential oil are related to its insecticidal activity (Sales et al., 2017). The $\mathrm{LC}_{50}$ of $57.4 \mu \mathrm{g} / \mathrm{mL}$ essential oil against fruit fly with, while $\mathrm{LC}_{50}$ of $38 \mu \mathrm{g} / \mathrm{mL}$ for worker termites (Shrestha et al., 2015). The insecticidal activity of $C$. citrinus leaf oil can be attributed to the major components 1,8-cineole , $\alpha$ terpineol, and eugenol (Bora and Khanikor, 2011).

The essential oils play an effective role in disrupting insect physiology in different manners. Moreover, the essential oils affect the insect nervous system by inhibiting (AChE) as insecticides (AbdelTawab, 2016). The most important compounds of insect are protein that binds with foreign compounds. The decrease of total protein in treated insect can affect the activity of various enzymes. In the same trend, protein is the major components which necessary for development, growth and performance of vital activities (Rashwan, 2013).

The essential oil of $C$. citrinus caused deficiency in the amount of total soluble protein at all concentrations used so the reduction of total soluble protein of supernatant of treated adult $N$. viridulla may be due to increased breakdown of proteins to detoxify the active principles. The explanation of these results supported by (El-barky et al., 2008) stated that inhibition of DNA and RNA Synthesis may lead to the reduction in protein content.

Amylase, trehalase and invertase enzymes involved in carbohydrates metabolism play an important role in the digestion and utilization of carbohydrates for production of needed insect energy. In this study the treatments cause elevation in amylase, trehalase and invertase enzymes. The reduction in total protein content and the increase in carbohydrate hydrolyzing enzymes could indicate mobilization of amino acids to supply energy which needed in detoxification process. (Gamil et al., 2011).
The highest elevation of $\alpha \& \beta$ estrases, ACP, ALP caused by the treatments of $C$. citrinus essential oil were observed. Esterases are a large group of hydrolases enzymes which hydrolyze numerous substances including esters and certain non-ester compounds, which split ester compounds with the addition of water to yield alcohol and acids (Shaurub et al., 1999) also, esterases play an important role in conferring or contributing to insecticide detoxifications in insect and arthropod species. In this respect Cai et al., 2009 suggesting that esterase enzymes are involved in detoxification of plant chemical defenses. Furthermore, Azab et al. (2011) concluded that, alkaline and acid phosphatase enzymes activities increased significantly in, Bemisia tabaci and Aphis gossypii after treated with damaseia extract.

The increase in the gut enzymatic activity after treatment may be related to the destructions of the mid-gut epithelial cell this may lead to intensive release of acid and alkaline phosphatases. Subsequently when the insect suffer from loss of weight and lake of feeding, the insect may try to compensate these pathological features by excess production of these enzymes for faster growth and development.

Apparently, increased activity of detoxification enzymes in adult of $N$. viridula indicated that the insect trial response to body intoxication with oil components of insect tissue degradation.

The $\mathrm{LC}_{50}$ of bottle brush essential oil caused inhibition of (AChE) while the induction action occurred at $\mathrm{LC}_{10}$ and $\mathrm{LC}_{25}$. (AChE) is a key enzyme in the nervous system which plays vital role in neurotransmission at cholinergic synapses by rapid hydrolysis of the neurotransmitter acetylcholine to choline and acetate. In general, many workers emphasized that essential oil induce mortality by inhibiting AChE activity in insect. In the same trend $\mathrm{Yu}$ et al. (2011) stated that the anti-AChE activity of essential oils is strongly dependent on the interaction of different terpenoid contents. In contrast the presence of oxygenated functional groups in bicyclic terpenes caused decrease its potent to inhibit AChE also the $\alpha$-pinene has been demonstrated as a potent $\mathrm{AChE}$ inhibitor (Miyazawa et al., 2005).

\section{CONCLUSION}

Based on the chemical constituent's properties of $C$. citrinus essential oil have a strong insecticidal and repellent activity against Nezara viridula. This oil has high potency in controlling the target pest. These findings are important and useful to incorporate $C$. citrinus essential oil into insect programs management.

\section{ACKNOWLEDGMENT}

The authors thank Dr. Hend M. Sabry Senior Researcher, plant protection research institute, agriculture research center for providing necessary research facilities.

\section{REFERENCES}

Abbott, W. S. (1925): Methods for computing the effectiveness of insecticide. J. Econ. Ent., 18(2): 256-267. 
Abdel-Tawab, H. M. (2016): Green Pesticides: Essential Oils as Biopesticides in Insect-pest Management. J. of Env. Sci. and Techno., 9(5): 354-378.

Akhtar, Y.; Pages, E.; Stevens, A.; Bradbury, R.; Da Camara, C. A. G. and Isman, M. B. (2012): Effect of chemical complexity of essential oils on feeding deterrence in larvae of the cabbage looper. Physiol. Entomol. 37,81-91.

Andola, H. C.; Haider, S. Z.; Negi, P. S. and Arunachalam, K. (2017): Composition of the Essential Oil of Callistemon citrinus (Curtis) Skeels from Uttarakhand (India). Natl. Acad. Sci. Lett., 40(5):389-392.

Aweke, N. and Yeshanew, S. (2016): Chemical Composition and Antibacterial Activity of Essential Oil of Callistemon citrinus from Ethiopia, European J. of Medicinal Plants, 17(1): 1-7.

Azab, M. M.; El- Lakwah, F. A.; Abd-El wahab, H.; Khattab, M. M. and El-Ghanam, M. S. M. (2011): Impact of certain insecticides on enzymes activity of whitefly Bemisia tabaci (Genn.) and aphids Aphis gossypii (Glover) on cucumber plants. Annals of Agric. Sci., Moshtohor. 49(2):191 -199.

Bora, D. and Khanikor, B. (2011): Selective toxicity of Ageratum conyzoides and Ocimum sanctum against Exorista sorbillans (Diptera:Tachinidae) and Antheraea ussama (Lepidoptera: Saturniidae). National Academy Science Letters. 34. 9-14.

Cai, Q. N.; Han, Y.; Cao, Y. Z.; Hu, Y.; Zhao, X. and Bi, J. L. (2009): Detoxification of gramine by the cereal aphid Sitobion avenae. J. Chem. Ecol., 35: 320325.

Chaubey, M. K. (2012): Acute, lethal and synergistic effects of some terpenes against Tribolium castaneum Herbst (Coleoptera: Tenebrionidae). Ecol. Balk, 4(1): 53-62.

Cornes, D. (2006): Callisto: a very successful maize herbicide inspired by allelochemistry. Proceeding of the fourth world congress on allelopathy. Wagga Wagga, NSW.

Costat Statistical Software (2005): Microcomputer program analysis version, 6.311. Co Hort Software, Monterey, California, USA.

El-barky, N. M.; Dahi, H. F. and El-Sayed, Y. A. (2008): Toxicological evaluation and biochemical impacts for radient as a new generation of spinosyn of Spodoptera littoralis (Boisd.), larvae. Egypt. Acad. J. Biol. Sci., 1(2): 85-97.

Fall, R.; Ngom, S.; Sall, D.; Sembene, M. and Samb, A. (2017): Chemical characterization of essential oil from the leaves of Callistemon viminalis (D.R.) and Melaleuca leucadendron (Linn.). Asian Pac. J. Trop. Biomed., 7(4): 347-351.

Gamil, W. E.; Mariy, F. M.; Youssef, L. A. and Abdel Halim, S. M. (2011): Effect of Indoxacarb on some biological and biochemical aspects of Spodoptera littoralis (Boisd.) larvae. Annals of Agricultural Sciences, 56(2): 121-126.

Gore, J.; Abel, C. A.; Adamczyk, J. J. and Snodgrass, G. (2006): Influence of soybean planting date and maturity group on stink bug (Heteroptera: Pentatomidae) populations. Env. Ent., 35: 531-536.
Gornall, J. G.; Bardwill, G. J. and David, M. M. (1949): Determination of serum protein by mean of biuret reaction. J. Bio. Chem., 117: 751-766.

Ishaaya, I. and Swiriski, E. (1976): Trehalase, invertase and amylase activities in the black scle, Saissetia oleae and their relation to host adablebility, J. Ins. Physiol., 16: 1025-1029.

Isman, M. B. (2000): Plant essential oils for pest and disease management. Crop. Prot., 19: 603-608.

Jazet, P. M.; Tatsadjieu, L. N.; Ndongson, B. D.; Kuate, J.; Zollo, P. A. and Menut, C. (2009): Correlation between chemical composition and antifungal properties of essential oils of Callistemon rigidus and Callistemon citrinus of Cameroon against Phaeoramularia angolensis. J. Med. Plants Res., 3:9-15.

Likenes, S. T. and Nickerson, G. B. (1966): Isolation and identification of volatiles. J. Chromatogr., 21: 1-8.

Liska, A.; Rozman, V.; Kalinovic, I.; Ivezic, M. and Balicevic, R. (2010): Contact and fumigant activity of 1,8-cineole, eugenol and camphor against Tribolium castaneum (Herbst). 10th International Working Conference on Stored Product Protection. Julius-K"uhn-Archiv, 425: 716-20.

Miyazawa, M. and Yamafuji, C. (2005): Inhibition of acetylcholinesterase activity by bicyclic monoterpenoids J. Agric. Food Chem., 53: 17651768.

Mollah, M. M. I.; Rahman, M. M.; Soyema, K.; Mukta, M. and Akon, M. R. (2017): Toxicity of botanical and chemical insecticides on stink bug complex (Heteroptera: Pentatomidae) in lablab bean (Lablab purpureus Lin.) field, J. of Ent. and Zoo. Studies, 5(2): 537-541.

Ndomo, A. F.; Tapondjou, A. L.; Ngamo, L. T.; Hance, T. (2010): Insecticidal activities of essential oil of Callistemon viminalis applied as fumigant and powder against two bruchids. J. Appl. Ent., 134(4):333-341.

Nguefack, J.; Torp, J.; Leth, V.; Lekane, D. J. B.; Fotio, D. and Amvamzollo, P. H. (2007): Effects of plant extracts and chemical fungicide in controlling a rice seed-born fungus under laboratory and in irrigated cropping system in Ndop-Cameroon. Afr. Crop Sci. Conf. Proc. 8:791-796.

Oyedeji, O. O.; Lawal, O. A.; Shode, F. O. and Oyedeji, A. O. (2009): Chemical composition and antibacterial activity of the essential oils of Callistemon citrinus and Callistemon viminalis from South Africa. Molecules, 14: 1990-1998.

Panizzi, A. R. (1997): Wild hosts of Pentatomids: ecological significance and role in their pest status crops. Ann. Rev. Ent., 42: 99-122.

Powell, M. E. A. and Smith, M. J. H. (1954): The determination of serum acid and alkaline phosphatase activity with 4-aminoantipyrine. J. Clin. Pathol., 7: 245-248.

Rashwan, M. H. (2013): Biochemical Impacts of Rynaxypyr (Coragen) and Spinetoram (Radiant) on Spodoptera littoralis (Boisd.). Nature and Sci., 11(8): 40-47. 
Salem, M. Z. M.; Ali, H. M.; El-Shanhorey, N. A. and Abdel-Megeed, A. (2013) Evaluation of extracts and essential oil from Callistemon viminalis leaves: Antibacterial and antioxidant activities, total phenolic and flavonoid contents, Asian Pacific J. of Trop. Medi., :785-791.

Sales, T. A.; Cardoso, M. D. G.; Guimarães, L. G. D. L.; Camargo, K. C.; Rezende, D. A. D. C. S.; Brandão, R. M.; Souza, R. V.; Ferreira, V. R. F.; Marques, A. E.; Magalhães, M. L. and Nelson, D. L. (2017): Essential Oils from the Leaves and Flowers of Callistemon viminalis: Chemical Characterization and Evaluation of the Insecticide and Antifungal Activities. American Journal of Plant Sciences, 8: 2516-2529.

Seyydnejad, S. M.; Niknejad, M.; Darabpoor, I.; Motamedi, H. (2010): Antibacterial activity of hydroalcoholyc extract of Callistemon citrinus and Albizia lebbek. Am. J. Appl. Sci. 7(1):13-16.

Shaurub, E. H.; Ali, G. M. and Megahed, F. M. A. (1999): Esterase isozymes in the overics of gammairradiated cotton leafworm Spodoptera littoralis (Boisd.), (Lepidopetra: Noctuidae). Bull. Ent. Soc. Egypt, Econ. Ser., 26: 109-122.

Shrestha, S.; Poudel, A.; Satyal, P.; Dosoky, N. S., Chhetri, B. K. and Setzer, W. N. (2015): Chemical composition and biological activity of the leaf essential oil of Callistemon citrinus from Nepal, American J. of Essential Oils and Natural Products, 3(1): 29-33.

Simpson, D. R.; Bulland, D. L. and Linquist D. A. (1964): A semi micro technique for estimation of cholinesterase activity in boll weevils. Ann. Ent. Soc. Amer., 57: 367-371.
Suthisut, D.; Fields, P. G.; Chandrapatya, A. (2011): Contact toxicity, feeding reduction, and repellency of essential oils from three plants from the ginger family (Zingiberaceae) and their major components against Sitophilus zeamais and Tribolium castaneum. J. Econ. Ent., 104(4):1445-54.

Van Asperen, K. (1962): A study of housefly esterase by means of sensitive colourimetric method. J. Insect Physiol., 8: 401-416.

Viswan, A. K.; Rahana, V. K. and Pushpalatha, E. (2014): Repellent and adulticidal efficacy of essential oils of two indigenous plants from Myrtaceae family against Lasioderma serricorne F. J. Biopest7 (Supp.):70-74.

Willrich, M. M.; Leonard, B. R. and Padgett, G. B. (2004): Influence of southern green stink bug, Nezara viridula L., on late-season yield losses in cotton, Gossypium hirsutum L. Envi. Ent., 33:1095-1101.

Yu, Z. W.; Wang, B. C.; Yang, F. M.; Sun, Q. Y.; Yang, Z. N. and Zhu, L. C. (2011): Chemical composition and antiacetylcholinesterase activity of flower essential oils of Artemisia annua at different flowering stage Iran. J. Pharm. Res., 10 (2): 265 271

Zandi-Sohani, N.; hojjati, M. and Carbonell-Barrachina, A. A. (2013): Insecticidal and Repellent Activities of the Essential Oil of Callistemon citrinus (Myrtaceae) against Callosobruchus maculatus (F.) (Coleoptera: Bruchidae). Neotropical Ent., 42: 8994.

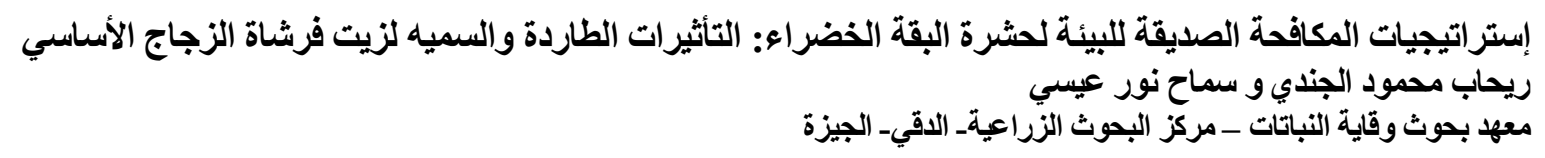

تم تقييم النشاط الحيوي للزيت العطري لاوراق اشجار فرشاه الزجاج ضد حشرة البقة الخضر اء كمبيد بديل صديق للبيئة. قد اظهر

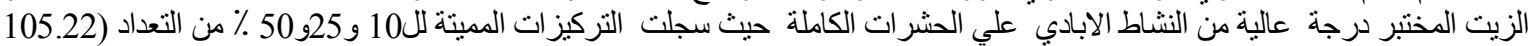

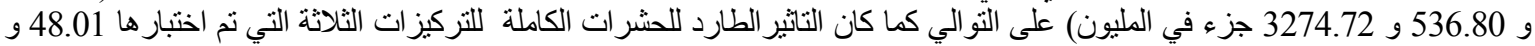

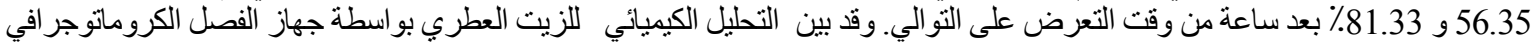

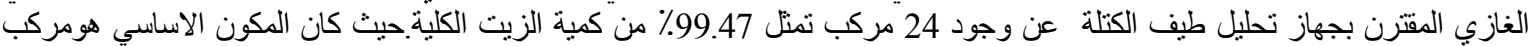

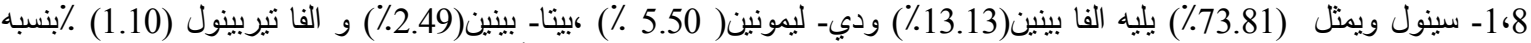

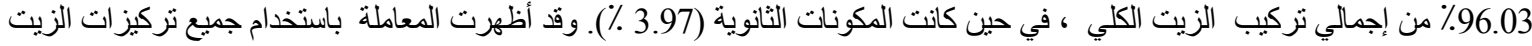

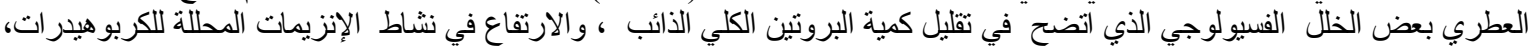

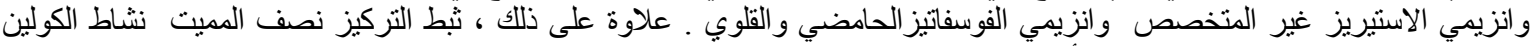

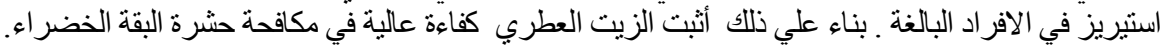

